\title{
Genetic Variability, Character Association and Divergence Study in Urdbean [Vigna mungo (L). Hepper]
}

\author{
Tushar Chowdhury, Arpita Das*, G. S. Mandal, \\ Sudip Bhattacharya and Shayree Chatterjee
}
Department of Genetics \& Plant Breeding, Bidhan Chandra Krishi Viswavidyalaya, Mohanpur, Nadia, West Bengal-741252, India

*Corresponding author

\begin{tabular}{|l|}
\hline Ke y w or d s \\
Genetic variability, \\
$\begin{array}{l}\text { Heritability, } \\
\text { Correlation, } \\
\text { Diversity, Urdbean }\end{array}$ \\
\hline Article Info \\
\hline $\begin{array}{l}\text { Accepted: } \\
\text { 08 January } 2020 \\
\text { Available Online: } \\
\text { 10 February } 2020\end{array}$ \\
\hline
\end{tabular}

\section{A B S T R A C T}

Urdbean is an important climate resilient pulse crop with excellent nutritional profile grown extensively in Indian subcontinent. The present investigation was conducted to study the genetic variability, association of the characters and diversity among 51 released varieties and advance breeding lines of urdbean considering yield and yield attributing traits. The experiment was conducted during kharif season of 2017 and 2018 in Randomized Block design maintaining two replications. Observation was recorded regarding nine yield and yield attributing traits for determining genetic variability, association of the characters and divergence among the tested genotypes. Significant variation was observed in terms of all the quantitative characters. Selection for the characters viz. plant height, branches plant ${ }^{-1}$, no. of pod plant ${ }^{-1}$, no. of seed pod $^{-1}$ and 100 seed weight would be effective for improvement of seed yield in these populations. Cluster analysis divided the population into ten clusters and indicated a considerable amount of divergence within and between the clusters with detection of diverse parents for future breeding programme. Presence of significant genetic variability and diversity among the tested genotypes of urdbean would be conducive for obtaining superior progenies in future breeding programme.

\section{Introduction}

Urdbean (Vigna mungo (L). Hepper) is a self pollinated diploid grain legume $(2 n=2 x=22)$ belongs to the Leguminaceae family with a genome size of $560 \mathrm{Mb}$ (Arumuganathan and Earle, 1991). It is an important short duration pulse crop mainly grown in South Asian regions in different seasons under rainfed based agro-ecosystems (Gupta et al., 2001) and now also started to grow in the Southern United States, West Indies, Japan and other tropics and subtropics (Delic et al., 2009). In India, urdbean is cultivated in an area of 3.06 million hectares with an average productivity of $555 \mathrm{~kg} \mathrm{ha}^{-1}$ and production of 1.70 million tonnes (Annoymous, 2018). Being a short duration legume it can fit well with any 
cropping system and enrich soil fertility status for fallow crop. Despite of immense potential, the productivity of this crop in India is very low due to various constraints like nonavailability of quality seed of high yielding varieties, pre-harvest sprouting, water logging and other abiotic and several biotic stresses. Thus, the crop requires due attention to increase its production and productivity.

The knowledge of nature and magnitude of correlation for characters of economic importance and cause and effects of relationship of yield and yield components for the available genotypes are of utmost essential which, helps in planning the future breeding programme for genetic improvement of any crop species (Reni et al., 2013; Panigrahi et al., 2014). Narrow genetic diversity is the main bottleneck for improving urdbean. Therefore, choice of diverse parents for hybridization is one of the important considerations for creating new genetic variability in this crop. Furthermore, monitoring the genetic variability within the gene pool of elite breeding material could make crop improvement more efficient by the directed accumulation of favoured alleles (Kanimozhi et al., 2009). Keeping these in the backdrop, the present study aimed to investigate the genetic variability, character association and divergence among 51 urdbean genotypes in terms of yield and yield attributing characters for identifying the important traits as well as diverse parents to be exploited for future breeding programme.

\section{Materials and Methods}

The present investigation was carried out during the kharif season of 2017 and 2018 at District Seed Farm $\left(21.5^{\circ} \mathrm{N}\right.$ latitude, $85^{\circ} \mathrm{E}$ longitude and altitude of $11.7 \mathrm{~m}$ above the Mean Sea Level), Bidhan Chandra Krishi Viswavidyalaya, Kalyani, Nadia, West Bengal. The soil of the experimental field at new alluvial zone is alluvial and sandy loam in texture having good water holding capacity (WHC), medium fertility status and neutral in reaction. Fifty one genotypes of urdbean including two checks (Sekhar-3, Uttara) collected from All India Co-ordinated Research Project on urdbean and other pulses (MULLaRP) were line sown following proper plant geometry with a row to row spacing of $40 \mathrm{~cm} \times 10 \mathrm{~cm}$ between row to row and plant to plant respectively. The experiment was conducted in Randomized Complete Block Design (RCBD) with 2 replications. Standard package of practices were followed to raise the crop. Observation on various yield attributing traits as well as yield viz. days to $50 \%$ flowering, Plant height $(\mathrm{cm})$, number of primary branches plant- ${ }^{-}$, number of pods plant $^{-1}$, number of seeds pod ${ }^{-1}$, pod length $(\mathrm{cm})$, days to maturity, 100 seed weight $(\mathrm{g})$ and seed yield plant $^{-1}$ (g) were recorded considering five competitive randomly selected plants from each replications.

The pooled experimental data of two years (2017 and 18) were used for statistical analysis by using MS EXCEL and OPSTAT online software. The total variations among genotypes for different characters were tested for significance by ' $\mathrm{F}$ ' test using analysis of variance technique, to find out the ' $F$ ' values from the table (Fisher and Yates, 1953). Phenotypic $\left(\sigma^{2} \mathrm{p}\right)$ and genotypic variance $\left(\sigma^{2} \mathrm{~g}\right)$, phenotypic coefficient of variation (PCV), genotypic coefficient of variation (GCV) were estimated using standard procedure (Singh and Chaudhary, 1995). Heritability was calculated according to Singh and Chaudhary, 1995; Genetic advance was estimated by the formula described by Allard (1960) and Correlation coefficient was calculated by the formula suggested by Johnson et al., (1955) and Al. Jibouri et al., (1958). Path coefficient analysis was carried out according to Dewey and Lu (1959). The analysis of genetic divergence was done using 
Mahalonobis (1936) $\mathrm{D}^{2}$ statistics. The genotypes were grouped into different clusters, inter and intra cluster distances and mean performances of characters were also computed.

\section{Results and Discussion}

Frequency distributions for the traits were enumerated to group the cultivars into different categories (Figure 1). It was observed that $35 \%$ of the genotypes were flowered within 38-42 days while, only $14 \%$ genotypes were identified as late flowering genotype and flowered within 46-50 days. Regarding pods plant $^{-1}$ it was detected that $61 \%$ genotypes having no. of pods ranged between 8.5-23.5 whereas, only $8 \%$ genotypes were having pods plant ${ }^{-1}$ more than 38 to 54 . Furthermore, only $6 \%$ genotypes were having pod length of up to $6.55 \mathrm{~cm}$, whereas, around $76 \%$ genotypes having pod length between $3.95-5.25 \mathrm{~cm}$. Among the tested genotypes only $4 \%$ of the genotypes matured beyond 82 days to 87 days. Regarding seed index, it was revealed that around $96 \%$ of the genotypes having 100 seed weight of up to $4.4 \mathrm{~g}$, whereas, only $6 \%$ genotypes were having bold seed with size ranged from 4.4-7.3 g. Finally, regarding yield plant $^{-1}$ it was detected that only $4 \%$ genotype yielded more than $11.81 \mathrm{~g}$ to 16.81 g.

The estimation of PCV (Table 1) ranged from $3.19 \%$ for days to maturity to $50.08 \%$ in yield plant ${ }^{-1}$, whereas for GCV it was $2.73 \%$ to $47.72 \%$ for the said characters respectively. The estimates of genotypic and phenotypic coefficient of variation (GCV and PCV) were high (>20\%) for branches plant ${ }^{-1}$, pod plant $^{-1}$, and for yield plant ${ }^{-1}$. On the contrary, moderate GCV and PCV (10-20\%) was observed in case of plant height, seeds $\operatorname{pod}^{-1}$ and for pod length. Characters like days to $50 \%$ flowering, branches plant $^{-1}$, pods plant $^{-1}$ and 100 seed weight exhibited low difference between PCV and GCV thus confirmed that there was very less effect of environment with greater role of genetic factors for controlling these traits. Results were in conformity with the reports of Priya et al., (2018) for PCV and GCV in case of days to $50 \%$ flowering and no. of branches plant $^{-1}$, Gowsalya et al., (2016) for no. of pods plant ${ }^{-1}$ and Kumar et al., (2015) for 100 seed weight. Moreover, no. of branches plant ${ }^{-}$ ${ }^{1}$, no. of pods plant ${ }^{-1}$ and seed yield plant ${ }^{-1}$ showed presence of high heritability coupled with high GA as \% of mean which indicated that there was preponderance of additive gene action governing these traits. Selection would be rewarding for improving these traits. The present study corroborated with the findings of Kanimoli et al., (2013) for heritability and GA as \% of mean in case of no. of branches plant $^{-1}$, Bandi et al., (2018) in case of no. of pods plant ${ }^{-1}$ and Gowsalya et al., (2016) for seed yield plant ${ }^{-1}$. Whereas, the presence of high heritability with moderate to low GA as $\%$ of mean for days to $50 \%$ flowering, no. of seeds $\operatorname{pod}^{-1}$, days to maturity and 100 seed weight indicated the influence of non-additive gene action which indicates epistasis, dominance and genotypic and environmental interaction hence their response to selection would be poor (Usharani and Kumar, 2016). Exhibition of moderate heritability was the effects of significant influence of environments towards this character and the observation was earlier confirmed by Punia $e t$ al., (2014). The results are in accordance with the findings of Toppo et al., (2019) in urdbean, Das et al., (2007) in greengram, Arshad et al., (2002) in chickpea and Malik et al., (2014) in soybean.

In the present study it was observed that for all the traits the genotypic correlation coefficient was higher than the phenotypic correlation coefficient thus confirmed less influence of environments towards 
influencing the expression of any characters (Figure 2). It was observed that at genotypic level, yield plant $^{-1}$ exhibited significant positive relationship with plant height, no. of branches plant ${ }^{-1}$, no. of pods plant ${ }^{-1}$, no. of seeds $\operatorname{pod}^{-1}$ and 100 seed weight. At phenotypic level all these characters revealed significant positive correlation with yield except plant height thus confirmed the importance of selection of superior genotypes based on these characters would be meaningful for improving urdbean yield. Similar results were reported by Bharti et al., (2014); Patidar et al., (2017) and Suryawanshi et al., (2018).

Table.1 Genetic parameters of nine yield and yield attributing traits in 51 genotypes of urdbean during kharif season of 2017 and 2018 (pooled)

\begin{tabular}{|c|c|c|c|c|c|c|}
\hline Parameters & Mean & Range & GCV & PCV & Heritability & $\begin{array}{c}\text { Genetic } \\
\text { advance as } \% \\
\text { of mean }\end{array}$ \\
\hline $\begin{array}{l}\text { Days to } 50 \% \\
\text { flowering }\end{array}$ & 42.86 & $38-48.5$ & 5.25 & 6.01 & 76.2 & 9.44 \\
\hline Plant height (cm) & 46.55 & $29.6-73.65$ & 17.25 & 19.6 & 77.4 & 31.25 \\
\hline Branches plant $^{-1}$ & 2.297 & $1.1-4.11$ & 40.54 & 40.82 & 98.6 & 83.14 \\
\hline Pods plant $^{-1}$ & 21.28 & $8.5-47$ & 40.48 & 41.7 & 94.2 & 80.95 \\
\hline Seeds pod ${ }^{-1}$ & 6.15 & $4.5-8$ & 10.86 & 14.55 & 55.7 & 16.75 \\
\hline Pod length (cm) & 4.47 & $2.65-5.6$ & 13.91 & 14.35 & 93.9 & 27.77 \\
\hline Days to maturity & 76.55 & $71.5-82.5$ & 2.73 & 3.19 & 73 & 4.80 \\
\hline 100 seed weight $(\mathrm{g})$ & 4.14 & $3.74-4.61$ & 4.62 & 4.73 & 95.4 & 9.42 \\
\hline Yield plant ${ }^{-1}(\mathrm{~g})$ & 5.03 & $1.81-12.98$ & 47.72 & 50.08 & 90.8 & 93.59 \\
\hline
\end{tabular}

Table.2 Genotypic path coefficient analysis of nine yield attributing traits in 51 genotypes of urdbean during kharif season of 2017 and 2018 (pooled)

\begin{tabular}{|c|c|c|c|c|c|c|c|c|c|}
\hline & $\begin{array}{c}\text { Days to } \\
50 \% \\
\text { flowering }\end{array}$ & $\begin{array}{c}\text { Plant } \\
\text { height } \\
\text { (cm) }\end{array}$ & $\begin{array}{c}\text { Branches } \\
\text { plant }^{-1}\end{array}$ & $\begin{array}{c}\text { Pods } \\
\text { plant }^{-1}\end{array}$ & $\begin{array}{l}\text { Seeds } \\
\text { pod }^{-1}\end{array}$ & $\begin{array}{l}\text { Pod } \\
\text { length } \\
(\mathrm{cm})\end{array}$ & $\begin{array}{c}\text { Days to } \\
\text { maturity }\end{array}$ & $\begin{array}{c}100 \text { seed } \\
\text { weight } \\
(\mathrm{g})\end{array}$ & $\begin{array}{l}\text { Yield } \\
\text { plant }^{-1} \\
(\mathrm{~g})\end{array}$ \\
\hline $\begin{array}{l}\text { Days to } 50 \% \\
\text { flowering }\end{array}$ & -0.075 & -0.003 & 1 & 0.027 & -0.039 & -0.002 & 0.063 & 0.002 & -0.026 \\
\hline Plant height (cm) & -0.022 & -0.011 & .001 & 0.148 & 0.138 & -0.008 & 0.014 & 0.035 & $0.294 *$ \\
\hline Branches plant $^{-1}$ & -0.004 & 0.003 & 0.013 & 0.323 & -0.011 & 0.001 & 0.009 & -0.012 & $0.318^{* *}$ \\
\hline Pods plant $^{-1}$ & -0.002 & -0.002 & 0.005 & 0.827 & 0.062 & -0.003 & 0.01 & 0.046 & $0.943 * *$ \\
\hline Seeds pod ${ }^{-1}$ & 0.009 & -0.005 & 0.002 & 0.165 & 0.31 & -0.014 & -0.014 & 0.028 & $0.479 * *$ \\
\hline $\begin{array}{l}\text { Pod length } \\
\text { (cm) }\end{array}$ & -0.008 & -0.004 & 0.004 & 0.098 & 0.187 & -0.023 & 0.006 & 0.016 & 0.272 \\
\hline Days to maturity & -0.066 & -0.002 & 0.002 & 0.115 & -0.06 & -0.002 & 0.071 & -0.014 & 0.044 \\
\hline 100 seed weight (g) & -0.001 & -0.003 & -0.001 & 0.302 & 0.07 & -0.003 & -0.008 & 0.125 & $0.481 * *$ \\
\hline
\end{tabular}


Figure.1 Percent frequency distribution for nine yield and yield attributing traits in 51 genotypes of urdbean during kharif season of 2017 and 2018 (pooled)

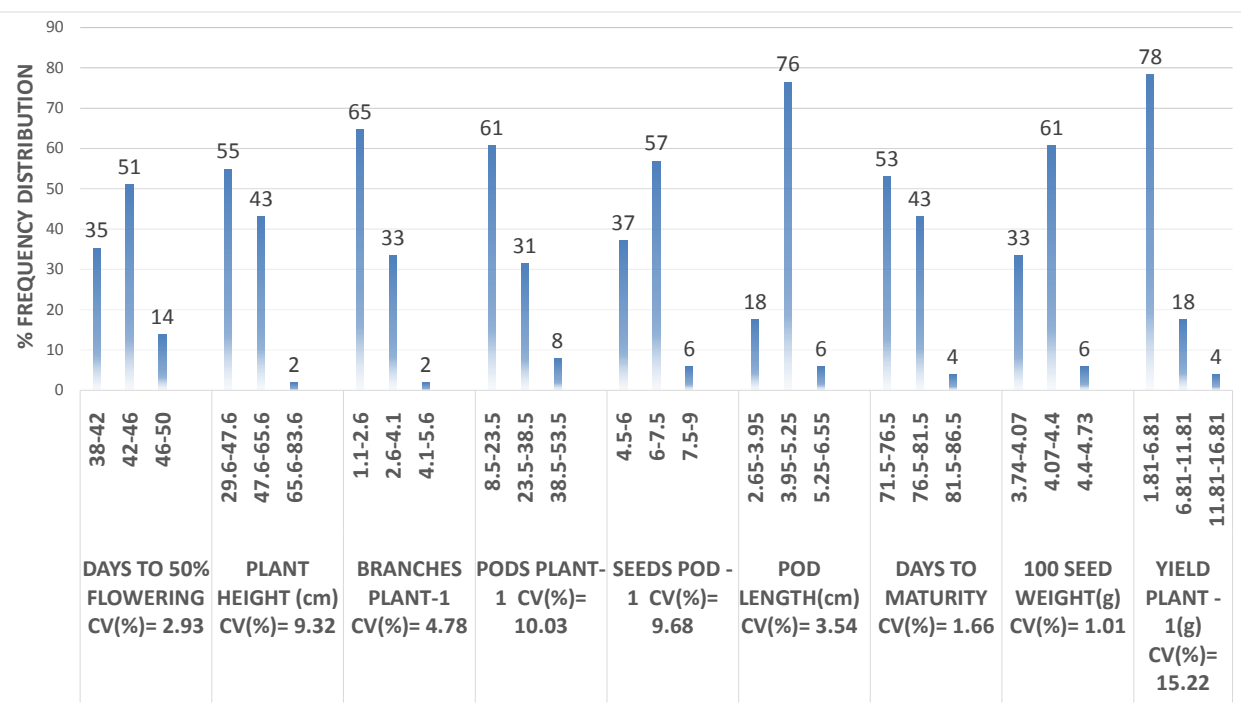

Figure.2 Genotypic (italics) and phenotypic correlations for yield and yield attributing traits in 51 genotypes of urdbean during kharif season of 2017 and 2018 (pooled)

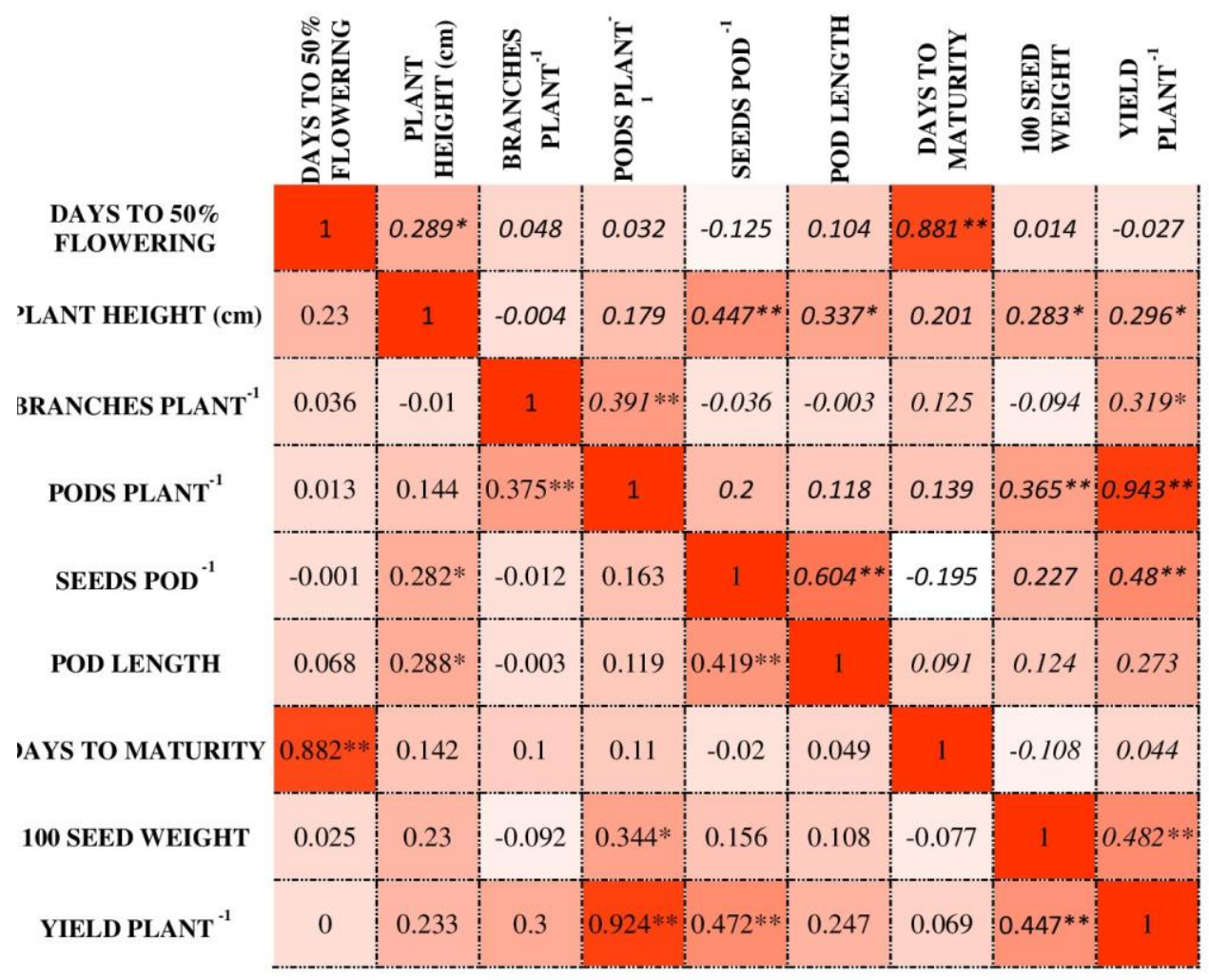


Figure.3 Dendrogram representing clustering of 51 urdbean genotypes based on Squared Euclidian distance matrix
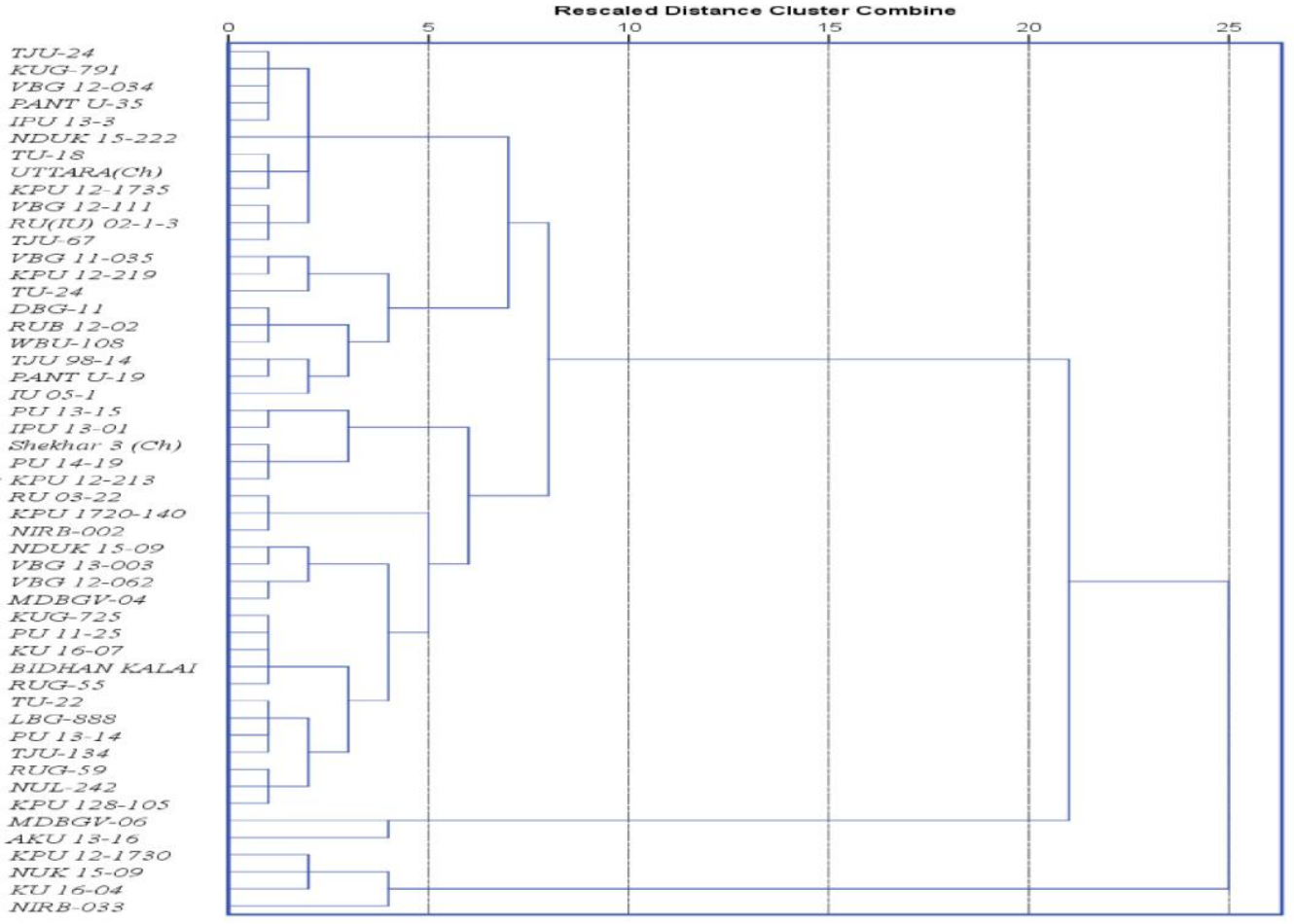

Figure.4 Intra and Inter-cluster distances of the 51 urdbean genotypes

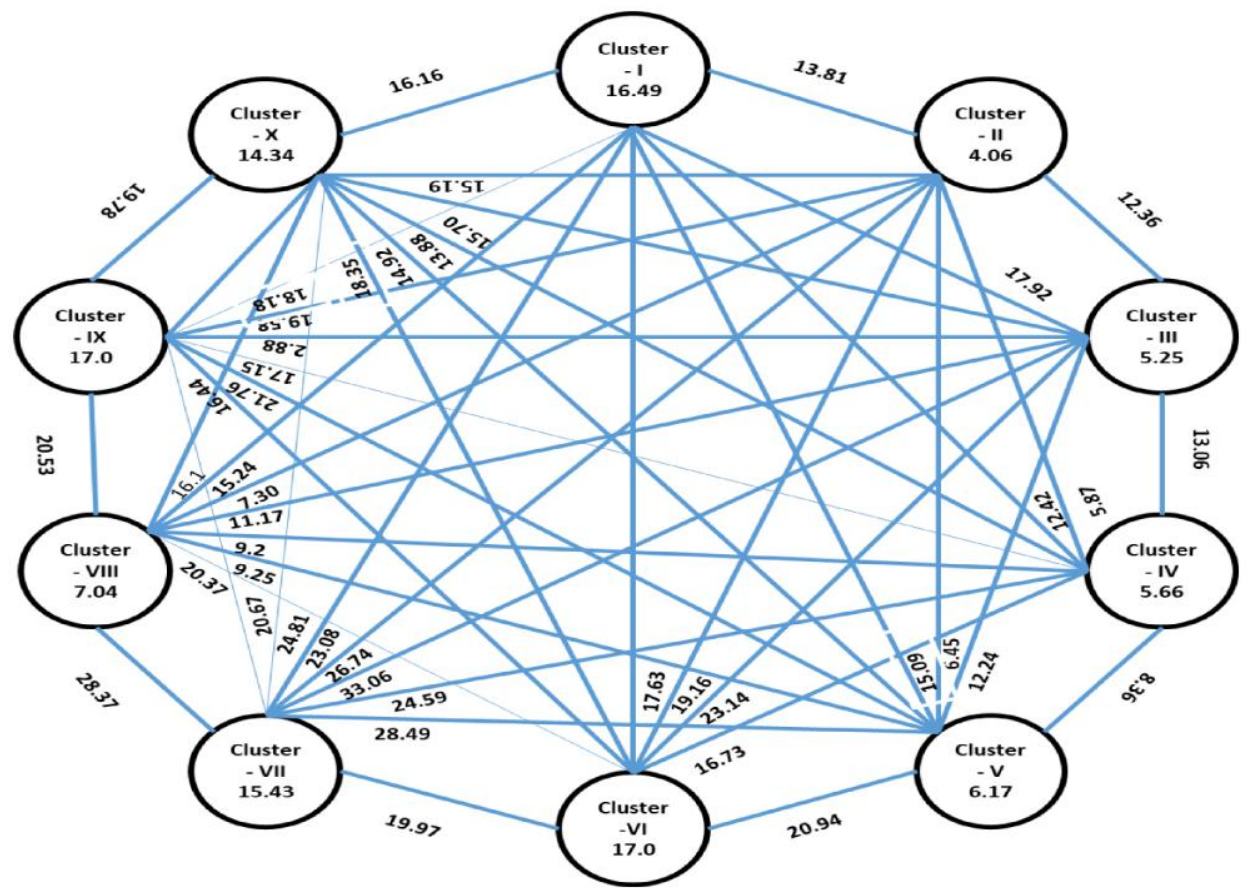


The knowledge regarding association of yield attributing traits and their relative contribution shown by path analysis has practical significance in selection as path analysis splits the interrelationship between two characters in to direct and indirect effects (Verma et al., 2015). Perusal of the data regarding genotypic path analysis revealed that no of pods plant ${ }^{-1}$, 100 seed weight, seeds pod ${ }^{-1}$, branches plant ${ }^{-1}$ and plant height exerted significant high positive direct effect on yield (Table 2). The residual effect in genotypic path coefficient (0.064) indicated that the nine characters included in this study explain the moderate percentage of variation in grain yield in this population. Similar findings were reported by Sohel et al., (2016), Priya et al., (2018), and Suryawanshi et al., (2018).

Genetic improvement of any crop mainly depends upon the amount of genetic variability present in the population. Information on genetic diversity within and among closely related crop germplasm is essential for rational use of genetic resources as a parent for obtaining higher amount of heterotic expression in $\mathrm{F}_{1} \mathrm{~s}$ and broad spectrum of variability in subsequent segregating generations. In order to assess the genetic diversity among 51 genotypes of urdbean, $\mathrm{D}^{2}$ statistic was used following the procedure given by Rao (1952). Since all the traits under study were correlated, they were transformed into uncorrelated linear combination through pivotal condensation method. All the genotypes of urdbean under study were distributed into 10 clusters such that the genotypes belonging to same cluster had an average smaller $\mathrm{D}^{2}$ values than those belonging to different clusters (Figure 3 ).

In the present study it was observed that cluster IX (12 genotypes) comprised of maximum number of genotypes followed by cluster I with 10 genotypes, cluster VI with 9 genotypes, cluster $\mathrm{X}$ with 6 genotypes whereas Cluster VII and VIII comprised of 3 genotypes each and cluster II, III, IV, V comprised of 2 genotypes each. Tendency to form clusters ignoring the geographical boundaries showed the regional isolation was not the only factor contributing to diversity in natural population (Das and Kumar, 2016). Formation of clusters among the genotypes of common geographic origin may be due to their parentage, developmental traits, past history of selection and different out-crossing rates (Arnold et al., 1996). Therefore, the kind of genetic diversity found among the genotypes belonging to same geographic origin might be due to difference in adoption, selection criteria, selection pressure and environmental conditions (Vivekananda and Subramanian, 1993).

The present study also revealed that the average intra cluster distance varied from 4.06 in cluster II to 17.002 in cluster VI and IX (Figure 4). The maximum intra cluster distance was observed between cluster VI and III (33.06) followed by cluster VII and V (28.491), cluster VIII and VII (28.37), cluster VII and II (26.74), and so on. This indicated considerable amount of divergence within and between clusters. Such highly divergent, high performing genotypes would be of great use in recombination breeding programme in order to get high heterotic recombinants. Keeping this in view, it could be concluded that genotypes from Cluster VI and III might be used as parents in the hybridization programme to generate breeding material with high diversity to get encouraging results. The results of this investigation collaborated with that of Kumar et al., (2014).

From the present study it can be concluded that adequate genetic variability was present in the tested urdbean genotypes. For improving grain yield emphasis should be given towards selection based on plant height, branches plant ${ }^{-1}$, no. of pod plant $^{-1}$, no. of seed $\operatorname{pod}^{-1}$ and 100 seed weight will be effective. Crossing involving genotypes from 
diverse group viz. VBG 12-111, RU(IU) 02-13 from cluster III with genotypes viz. Uttara, KPU 12-1730, KU 16-07, IU 05-1, RUG-55 etc. from cluster VI may produce wide spectrum of segregants and create opportunity for getting desirable transgressive segregants in future urdben breeding programme.

\section{Acknowledgment}

We, the authors, are thankful to AICRP on MULLaRP and BCKV, Mohanpur for providing us the urdbean accessions and technical support for field experiments, respectively.

\section{References}

Al-Jibouri, H., Miller, P. A. and Robinson, H.F., 1958. Genotypic and Environmental Variances and Covariances in an Upland Cotton Cross of Interspecific Origin 1. Agron. J., 50 (10): 633-636.

Allard, R. W., 1960. Selection under selffertilization. Principles of Plant Breeding, John Wiley \& Sons, Inc, 55.

Anonymous, 2018. Pulses revolution from food to nutritional security, Crops Division Government of India, Ministry of Agriculture \& Farmers Welfare, Department of Agriculture, Cooperation \& Farmers Welfare, Krishi Bhavan, New Delhi - 110001

Arnold, W. S., Bert, T. M., Marelli, D. C., Cruz-Lopez, H. and Gill, P. A., 1996. Genotype-specific growth of hard clams (genus Mercenaria) in a hybrid zone: variation among habitats. Marine Biol., 125 (1): 129-139.

Arumuganathan, K. and Earle, E. D. 1991. Nuclear DNA content of some important plant species. Plant Mol. Biol. Reporter. 9 (3): 208-218.

Bandi, H. R. K., Rao, K. N., Krishna, K. V. and Srinivasulu, K., 2018. Variability, Heritability and Genetic Advance for Quantitative Characters in Rice Fallow Blackgram [Vigna mungo (L.) Hepper].
Int. J. Curr. Microbiol. App. Sci, 7 (2): 171-176.

Bharti, B., Kumar, R., Bind, H. N., Kumar, A. and Sharma, V., 2014. Correlation and path analysis for yield and its components in blackgram (Vigna mungo L.). Int. J. Plant Sci. 9 (2): 410-413.

Das, A. and Kumar, D., 2016. Genetic divergence and character association for yield and quality attributing characters in tossa jute (Corchorus olitorius L.). Electron. J. Plant Breed., 7 (3): 529-537.

Delic, D., Stajkovic, O., Kuzmanovic, D., Rasulic, N., Knezevic, S. and Milicic, B., 2009. The effects of rhizobial inoculation on growth and yield of Vigna mungo L. in Serbian soils. Biotechnol. Animal Husband., 25: 1197-1202.

Dewy, D. R. and Lu, K. H., 1959. A correlation and path analysis of components of crested wheat seed production. Agron. J., 51 (9): 515-518.

Fisher, R. A. and Yates, F., 1953. Statistical tables for agricultural, biological and medical research. Edinborough, Oliver \& Boyd.

Gowsalya, P., Kumaresan, D., Packiaraj, D. and KannanBapu, J. R., 2016. Genetic variability and character association for biometrical traits in blackgram (Vigna mungo (L.) Hepper). Electron. J. Plant Breed. 7 (2): 317-324.

Gupta S., Gupta S. R., Dikshit H. K. and Singh. R. A., 2001.Variability and its characterization in Indian collections of blackgram. Plant Genet. Resour. Newslet., 127:20-24

Kanimoli, S., 2013. Occurrence, distribution and N. Asian J. Bio Sci., 8 (2): 229-233.

Kanimozhi, M., Jayamani, P. and Nadarajan, N., 2009. Genetic diversity as assessed by ISSR markers in Blackgram (Vigna mungo (L.) Hepper). Electron. J. Plant Breed. 1 (1): 12-17.

Kumar, P., Pandey, S. K. and Kumar, P., 2015. Effect of Different Phosphorus Level on Nutrient Content, Uptake and Economics of Urdbean under Custard Apple based Agri-Horti System. J. Agri. Search. 2 (2): 
88-93.

Kumar, Y. L., Anuradha, C. H., Reddy, S. S. and Subbaiah, K. V., 2014. Genetic divergence and Variability Studies in Blackgram (Vigna mungo L. Hepper). J. Agric Sci, 5 (6): 1299-1303.

Mahalonobis, P. C. 1936. On the generalized distance in statistics. Proc. Nat. Acad. Sci., 2: 49-55.

Panigrahi, K. K., Mohanty, A. and Baisakh, B., 2014. Genetic divergence, variability and character association in landraces of blackgram (Vigna mungo [L.] Hepper) from Odisha. J. Crop Weed. 10 (2): 155165.

Patidar, M. and Sharma, H., 2017. Correlation and path coefficient studies in Blackgram (Vigna mungo (L.) Hepper). J. Pharmacog. Phytochem. 6 (4): 16261628.

Priya, L., Pillai, M. A., Shoba, D., Kumari, S. M. P. and Aananthi, N., 2018. Research Note Genetic variability and correlation studies in black-gram [Vigna mungo (L.) Hepper]. Electron. J. Plant Breed. 9 (4): 1583-1587.

Punia, S. S., Gautam, N. K., Ram, B., Verma, P., Dheer, M., Jain, N. K. et al., 2014. Genetic variability and correlation studies in urd bean (Vigna mungo L.). Legume Res., 37 (6): 580-584.

Rao, C. R., 1952. Advanced Statistical Methods in Biometrical Research, John Wiley and Sons, New York.

Reni, Y. P., Rao, Y. K., Satish, Y. and Babu, J. S., 2013. Estimates of genetic parameters and path analysis in blackgram (Vigna mungo (L.) Hepper). Int. J. Plant Animal and Env. Sci. 3 (4): 231-234.

Sandhya, M., Kumari, S. and Babu, G. S., 2015.
Estimation of genetic divergence among elite genotypes of rice (Oryza sativa L.). The Ecoscan, 9 (1\&2): 409- 411.

Singh, R. K. and Chaudhary, B. D., 1979. Biometrical methods in quantitative genetic analysis, Kalyani Publishers, Dudhiano.

Sohel, M. H., Miah, M. R., Mohiuddin, S. J., Islam, A. K. M. S., Rahman, M. M. and Haque, M. A., 2016. Correlation and path coefficient analysis of Blackgram (Vigna mungo L.). J. Biosci. Agril. Res. 7 (2): 621-629.

Suryawanshi, N. A., Lal, G. M. and Warkad, S. D., 2018. Correlation and Path Analysis for Yield and Yield Components in Black gram [Vigna mungo (L.) Hepper]. Int. J. Current Microbiol. Applied Sci. 7 (8): 612-621.

Toppo, N. A., Nair, S. K. and Nanda, H. C., 2019. Genetic variability studies on yield and yield contributing traits in blackgram (Vigna mungo (L.) Hepper. J. Pharmacog. Phytochem., 8 (6): 17131716.

Usharani, K. S., and Kumar, C. A. (2016). Estimation of variability, heritability and genetic advance in mutant populations of black gram (Vigna mungo L. Hepper). SABRAO J. Breed. Genet., 48 (3): 258265.

Verma, A. K., Jyothi, K. U. and Rao, A. D., 2015. Variability and character association studies in dolichos bean (Lablab purpureus L.) genotypes. Indian J. Agric. Res., 49: 46-52

Vivekananda, P. and Subramanian, S., 1993. Genetic divergence in rainfed rice. Oryza, 30: 60-62.

\section{How to cite this article:}

Tushar Chowdhury, Arpita Das, G. S. Mandal, Sudip Bhattacharya and Shayree Chatterjee. 2020. Genetic Variability, Character Association and Divergence Study in Urdbean [Vigna mungo (L). Hepper]. Int.J.Curr.Microbiol.App.Sci. 9(02): 1726-1734.

doi: https://doi.org/10.20546/ijcmas.2020.902.198 